\title{
Progress, Challenges, and Perspectives of Bioleaching for Recovering Heavy Metals from Mine Tailings
}

\author{
Xiufang Gao $\mathbb{D}^{1}{ }^{1}$ Li Jiang, ${ }^{2}$ Yilin Mao, ${ }^{2}$ Bin Yao, ${ }^{3}$ and Peihua Jiang ${ }^{2}$ \\ ${ }^{1}$ Engineering Research Center of Ecology and Agricultural Use of Wetland, Ministry of Education, Jingzhou, China \\ ${ }^{2}$ College of Resources and Environment, Yangtze University, Wuhan, China \\ ${ }^{3}$ College of Resources and Environment, Hunan Agricultural University, Changsha 410128, China
}

Correspondence should be addressed to Xiufang Gao; 664039407@qq.com

Received 6 March 2021; Revised 13 April 2021; Accepted 26 April 2021; Published 7 May 2021

Academic Editor: Haijian Bing

Copyright (c) 2021 Xiufang Gao et al. This is an open access article distributed under the Creative Commons Attribution License, which permits unrestricted use, distribution, and reproduction in any medium, provided the original work is properly cited.

The accumulation of mine tailings on Earth is a serious environmental challenge. The importance for the recovery of heavy metals, together with the economic benefits of precious and base metals, is a strong incentive to develop sustainable methods to recover metals from tailings. Currently, researchers are attempting to improve the efficiency of metal recovery from tailings using bioleaching, a more sustainable method compared to traditional methods. In this work, the research status of using biological leaching technologies to recover heavy metals from tailings was reviewed. Furthermore, CiteSpace 5.7.R2 was used to visually analyze the keywords of relevant studies on biological leaching of tailings to intuitively establish the current research hotspots. We found that current research has made recent progress on influencing factors and microbial genetic data, and innovations have also been made regarding the improvement of the rate of metal leaching by biological leaching combined with other technologies. This is of great significance for the development of bioleaching technologies and industrial production of heavy metals in tailings. Finally, challenges and opportunities for bioleaching provide directions for further research by the scientific community.

\section{Introduction}

Rapid social and industrial developments have resulted in an increased demand for metals. As a result of rapid industrial development combined with increased exploitation of large quantities of mine resources, the environmental pollution of tailings is expanding at an alarming rate. The environmental impacts of tailings will eventually directly or indirectly threaten the human health (Figure 1). In soil and sediment, chemical pollutants caused by human activities have accumulated over 2,000 years. An early example of such pollution is heavy-metal mining waste. The environmental challenges posed by huge volumes of tailings and tailings dumps are often overshadowed by the economic benefits of mining. Tailings contain harmful quantities of toxic substances that can potentially pose serious health and environmental problems through air dispersion of air-dried tailings, leaching of potentially toxic chemical species, erosion and uptake by the aquatic system, and bioaccumulation [1].
Heavy metal contamination from tailings is detrimental to the human and environmental health [2]. The Luhun Reservoir, Henan Province, China, is located downstream of a molybdenum mining area. A recent study assessing the pollution of the reservoir found that molybdenum was the main pollutant in the overlying water of the reservoir, with the single element pollution factor $(P i)$ of molybdenum which is the highest among all heavy metals, at a mean value of 2.05 [3]. Similarly, there are a large number of gold mine tailings in the Welkom and Virginia areas of the Free State Province in South Africa. According to the World Health Organization and the South African National Drinking Water Standard, an analysis of the groundwater quality in the target area found that $40 \%$ of the analyzed samples contained lead exceeding the drinking water quality standard limit, 63\% contained iron exceeding the standard limit, $100 \%$ contained faecal coliform bacterial counts noncompliant with the current guidelines, and 50\% contained E. coli counts exceeding the standard limit [4]. Because groundwater is the main 


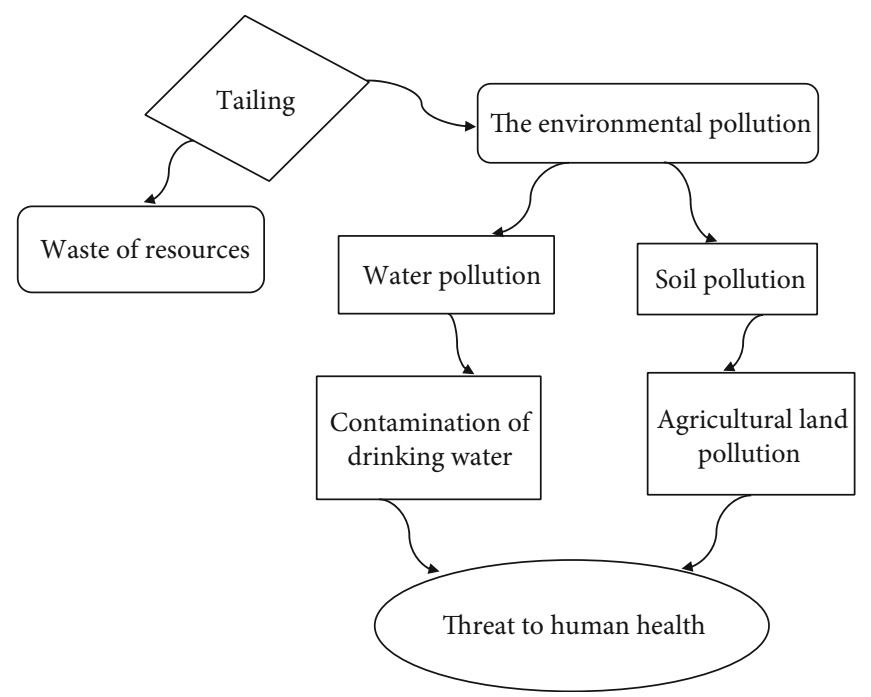

FIGURE 1: The harm of tailing pollution.

source of drinking water for the local population, this pollution poses a serious threat to their health. Furthermore, environmental pollution indirectly harms other organisms. In the city of Vicosa do Ceara/CE in northeastern Brazil, Fabio et al. (2021) assessed the impact of an abandoned copper mine on the environmental quality of the ecosystem through a comprehensive ecological and biogeochemical analysis. Their results showed that there was still a large amount of copper in the waste rock of the abandoned copper mine after 30 years of weathering, and drainage from the mine significantly reduced the aquatic macroinvertebrates and increased the copper content in living organisms [5].

Heavy metal pollution from tailings also seriously damages local land resources. Heavy metal mining and processing activities in southern Poland led to heavy zinc pollution and moderate lead pollution of the local agricultural land and thus agricultural production in these areas; as a result, the planting of green leafy vegetables was banned, which has led to significant economic losses [6].

As discussed above, the environmental risks of heavy metals from mining are very severe. However, tailings are also an important secondary resource. Gold, silver, lead, zinc, sulphur, indium, gallium, cadmium, germanium, selenium, tellurium, and other associated elements recovered from Chinese copper ore during the processing and smelting process account for $44 \%$ of the total output value of the raw materials; associated gold accounts for more than $35 \%$ of China's gold reserves, of which $76 \%$ of gold and $32.5 \%$ of silver is produced by copper mines [7]. Moreover, rare earth elements are essential components of high-tech electronic and electrical materials, and reserves of natural rare earth elements are limited worldwide, except in China [8]. However, many mine tailings are rich in mineralassociated rare earth elements, and such tailings are thus an important source. Therefore, in order to solve the shortage of metal resources and the problem of tailing pollution, suitable, effective, and economical technologies are needed for recovery and removal of heavy metals from mine tailings [9].
Fortunately, various methods have been developed in recent years to recycle tailings, including the promising technique of bioleaching, chemical extraction remediation techniques, and electrochemical repair techniques, that convert waste into value. Chemical extraction is limited by soil complexity and extractants. Electrochemical repair techniques are expensive and require complex operations. However, bioleaching is a low-cost, green technology for leaching metals from a variety of minerals and waste materials [10]. In the early 1950s, Colmer was the first to extract copper from a mine dump at the Kennecott Copper Corporation using microorganisms [11]. Thus, bioleaching technology opened the era of microbial metallurgy. Biological leaching refers to the direct action of some microorganisms in nature or the indirect action of their metabolites to produce oxidation, reduction, complexation, adsorption, or dissolution, by which processes certain insoluble components (such as heavy metals and other metals) are separated from the solid phase. The microorganisms used in biological leaching are mainly eosinophilic, inorganic autotrophic bacteria. Acidithiobacillus ferrooxidans, Acidithiobacillus thiooxidans, and Leptospirillum ferrooxidans are the most widely used. Currently, most minerals and ores are processed at the industrial scale using bioleaching [12]. For example, approximately $20-25 \%$ of the world's total copper are produced using bioleaching [13]. However, biological leaching technology has its limitations, such as the microbial leaching efficiency and reaction cycle.

Advances in molecular biology techniques and their applications in biosynthesis to detect and identify organisms have expanded our understanding of the interactions of metallic microbes and their important role in metal extraction and recovery [14]. This provides a good impetus for the industrial application of heavy metals from biological leaching of tailings.

This review provides an overview of the mechanisms and influencing factors of bioleaching technologies and provides a general understanding of the current status of the bioleaching of copper, iron, and zinc tailings, rare earth elements, and 
four toxic metals. The challenges and opportunities for the recovery of heavy metals from tailings by biological leaching are also discussed, which will provide a valuable reference for the full exploitation and utilization of secondary resources and the industrial development of the recovery of heavy metals from tailings using biological leaching technologies.

\section{Progress}

\subsection{Mechanisms and Methods}

2.1.1. Biological Leaching Mechanism. The essence of the biological leaching process is that Thiobacillus acquires the energy needed for growth by oxidizing reduced sulphur compounds, which leads to a decrease in the $\mathrm{pH}$ value and changes in the redox environment of the environmental system, thus changing the state of the heavy metals in the system from the original organic matter-bound state to the free state. Since the early 1950s, Fe/S-oxidizing bacteria have been used in industrial-scale processes to extract metals from sulphide ores [11]. The first isolated and most widely studied Fe/S-oxidizing bacteria are A. ferrooxidans; therefore, most of the research on the mechanism of bioleaching has been limited to the behavior of $\mathrm{A}$. ferrooxidans in the bioleaching of sulphide minerals [15]. The mechanisms of bioleaching of sulphide ore by A. ferrooxidans are divided into direct and indirect mechanisms.

Direct mechanisms: the microorganisms oxidize sulphide minerals through direct attack on the mineral surface [16] and possibly by the cell's unique oxidase system that directly oxidizes sulphide minerals. Hydrogen ions are produced simultaneously, resulting in a decrease in the $\mathrm{pH}$ of the environmental system and an increase in the redox potential and thus the formation of soluble sulphates [17]. However, it is difficult to distinguish between the bacterial cell wall and the molecular film of sulphide; therefore, this mechanism is more suitable for contact leaching [18]. This can be expressed in terms of the following reaction equation (1):

$$
\mathrm{MS}+2 \mathrm{O}_{2} \stackrel{\text { A.ferrooxidans; A.thiooxidans }}{\longrightarrow} \mathrm{MSO}_{4} \text {. }
$$

Indirect mechanisms: metabolites of Fe/S-oxidizing bacteria are used in redox reactions that occur with sulphide minerals, and finally, a redox circulatory system is formed. The sulfuric acid produced reduces the $\mathrm{pH}$ of the environmental system to approximately 2.0 and greatly promotes the dissolution of heavy metals [19]. Indirect mechanisms can be summarized by the following reaction equation (2) (taking pyrite as an example):

$$
4 \mathrm{FeS}_{2}+15 \mathrm{O}_{2}+2 \mathrm{H}_{2} \mathrm{O} \stackrel{\text { A.ferrooxidans }}{\longrightarrow} 2 \mathrm{Fe}_{2}\left(\mathrm{SO}_{4}\right)_{3}+2 \mathrm{H}_{2} \mathrm{SO}_{4} \text {. }
$$

Another approach is to complement the indirect mechanism by characteristics of bacterial attachment to mineral surfaces, in which the attached cells oxidize ferrous ions into iron ions within a layer of bacteria and extracellular poly- meric substances, and the ferric ions within this layer leach the sulphide [20].

In summary, all previous studies have found that the key to the exploration of the mechanism of biological leaching lies in microorganisms. Only by thoroughly studying the behavior of microorganisms in the leaching process can the mechanism of biological leaching be accurately and systematically interpreted, which will also depend on developments in molecular biology and other disciplines.

2.1.2. Microbe Overview. Bioremediation technology has attracted increasing attention in the field of environmental protection. At its core, the mechanism and species selection of microorganisms in pollution remediation have become the focus of research. In bioleaching, bacteria play a catalytic role [18], which is key to the industrialization of recovering heavy metals from tailings by biological leaching. Using microorganisms to extract heavy metals from tailings is more ecologically friendly, which not only controls tailings pollution but also alleviates the shortage of primary resources and will not produce harmful gases to form secondary pollution during the entire reaction process. A. ferrooxidans, A. thiooxidans, and L. ferrooxidans are the most commonly used microorganisms in bioleaching of heavy metals from tailings. Their physicochemical properties are presented in Table 1. As for energy sources, A. ferrooxidans, A. thiooxidans, and L. ferrooxidans get their energy from iron, sulphur, and iron, respectively.

Regarding the selection of microbial species, natural microorganisms (indigenous microorganisms) show better adaptability and have a higher leaching rate; therefore, the majority of studies to date used indigenous microbes [21, 22]. For example, indigenous bacteria can mediate electrochemical morphology and thus significantly improve arsenic leaching from tailings; thus, without effective treatment of arsenic-containing tailings, enhanced arsenic migration by indigenous bacteria will increase the risk of environmental contamination [23].

In terms of the selection of microbial diversity, mixed bacteria leaching is more efficient, and the majority of studies to date focused on the use of mixed bacteria leaching $[24,25]$. In a study of bioleaching of heavy metals from copper and silver mine tailings in the Philippines, the microbe cultures used were single bacterial and mixed cultures, respectively. The results showed that the leaching rate of copper and arsenic of the mixed bacteria was higher than that of the single bacteria, and the single bacteria and the mixed bacteria mediated the occurrence pattern of heavy metals in different ways [26]. Due to the synergistic effect of mixed bacteria, higher bacterial concentrations and copper extraction rates could be obtained in the biological leaching, and the highest copper extraction rate of mixed bacteria (73.7\%) was significantly higher than that of any single bacterial culture [27]. One study proposed that the highest bioleaching rate of valuable metals could be obtained using a natural consortium of drainage water combined with iron-oxidizing $\mathrm{L}$. ferrooxidans Teg [28].

The whole process of biological leaching can be summarized from the aspects of microbial species, diversity, bacterial 
TABle 1: Physical and chemical properties of microorganisms.

\begin{tabular}{lccc}
\hline Strain & Shape & Optimum $\mathrm{pH}$ & Optimum temp $\left({ }^{\circ} \mathrm{C}\right)$ \\
\hline Acidithiobacillus ferrooxidans & Rod-shaped & $2-3$ & $30-35$ \\
Acidithiobacillus thiooxidans & Rod-shaped & $1.5-2.0$ & $28-30$ \\
Leptospirillum ferrooxidans & Vibrioid-shaped & $1.5-2.0$ & $25-35$ \\
\hline
\end{tabular}

TABLE 2: Experimental equipment and functions commonly used in biological leaching experiment.

\begin{tabular}{lc}
\hline Instruments or methods & Functions \\
\hline Inductive coupled plasma atomic emission spectrometry (ICP-OES) & Determination of metal content \\
Atomic absorption spectrophotometer (AAS) & Determine the concentration of metal in solution \\
pH meter and redox potential analyzer & Determine pH values and redox potential Eh \\
Fourier transform infrared spectrometers (FTIR) & Qualitative and quantitative analysis of samples \\
X-ray diffractometer (XRD) & Mineralogical analysis \\
Phenanthroline spectrophotometry & Determination of ferrous ion and total iron concentration \\
16S rRNA gene sequencing & Monitor microbial distribution \\
\hline
\end{tabular}

density, activity, and distribution as follows [29-31]: Biological leaching is a continuous reaction process, and the best microorganisms are selected according to the characteristics of these processes; generally, mixed strains and indigenous strains have high leaching rates, and the higher the number and activity of microorganisms, the higher the leaching rate; microorganisms are uniformly distributed in stirred tank reactors, but not in leaching heaps, which are one of the reasons why the industrial application of biological leaching of heavy metals from tailings is limited.

In the future, the microorganism selection related to bioleaching needs to be further improved in several aspects [32]: (1) seeking a microorganism that can achieve oxidation reactions in alkaline environments is conducive to the extraction of alkaline minerals, and the application of biological leaching could be expanded; (2) to strengthen the tracking of microbial morphology and species changes before and after leaching, to better explore the microbial mechanism and improve leaching efficiency [33]; and (3) identification and development of chlorine-tolerant organisms can promote the utilization of seawater or brackish water in bioleaching, reduce the cost, and at the same time benefit the reality of freshwater resource shortages.

2.1.3. Bioleaching Methods. The commonly used experimental equipment and their functions in biological leaching of heavy metals from tailings are listed in Table 2.

Biological leaching methods for the treatment of electronic waste can be divided into three types according to the type of biomass exposure to the waste: one-step, two-step, and spent-medium [34]. In the study of biological leaching of heavy metals from tailings, the operation steps are generally as follows (Figure 2): first, the tailing samples are collected and treated, and physical and chemical analyses are carried out; second, the bacterial strains are screened and identified, enriched in a sterile environment, and the bacterial solution is preacidified; finally, a certain amount of tailing sample and bacterium fluid is placed in a $250 \mathrm{~mL}$ conical flask, the blank control group is set up, and all conical flasks are placed in a constant temperature oscillating shaker at an appropriate temperature for the bioleaching experiment. The specific experimental conditions are selected according to the species and mineral types. Any evaporated water in the experiment is replenished with ultra-pure water, and the $\mathrm{pH}$ and redox potentials are measured daily. Furthermore, the supernatant is collected daily to analyze the heavy metal content in the solution. All instruments used in the experiment should be sterilized by such techniques as high-temperature sterilization, adding sodium azide, etc.

\subsection{Analysis of Factors Influencing Biological Leaching}

2.2.1. $\mathrm{pH}$ and Redox Potential. The $\mathrm{pH}$ is an important physical and chemical parameter in biological leaching. In the study of bioleaching of heavy metals from tailings, iron/sulfur-oxidizing bacteria are more likely to undergo redox reactions under acidic conditions. The effect of $\mathrm{pH}$ on the optimum leaching rates of different metals is different. In one study, when the slag particle size was less than $0.83 \mathrm{~mm}$, the smelting slag of lead/zinc on copper, iron, lead, zinc, and other metals was highly dependent on $\mathrm{pH}$, but the $\mathrm{pH}$ had little influence on the solubilization of manganese [35]. Before the bioleaching reaction took place, the $\mathrm{pH}$ of the bacterial solution was adjusted to reach the optimum $\mathrm{pH}$ range for the microorganisms. During the reaction, the change in $\mathrm{pH}$ will affect the microbial activity and thus the metal leaching rate; therefore, it is very important to monitor the change in $\mathrm{pH}$ during the reaction. One study found that preacidification treatment was needed to ensure the leaching rate of heavy metals [36], but not all biological leaching experiments need preacidification treatment, and another study found that when there was no preacidification treatment, the addition of an right amount of substrate impart a buffering action to make the $\mathrm{pH}$ of the reactor more stable and gradually decreased [37]. 


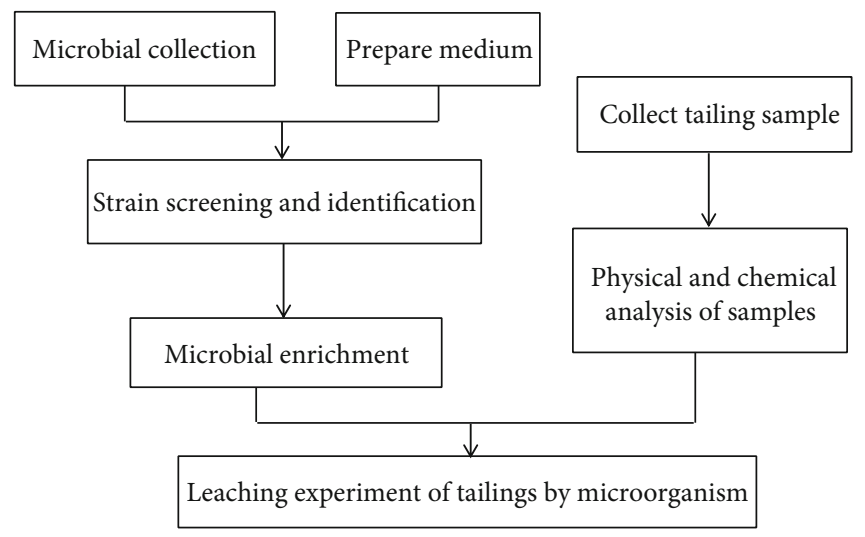

FIgURE 2: Technical flow of heavy metals from bioleaching tailings.

A different study showed that the reduction potential of the solution had a great influence on the leaching rate of pyrite, and the influence degree was much greater than the number and activity of bacterial cells [38]. A high oxidation-reduction potential (ORP) reflects high biomass concentration, and the bioleached chalcopyrite was controlled by ORP under high $\mathrm{pH}$ [39].

2.2.2. Temperature. Temperature is one of the important influencing factors in the process of bioleaching. It mainly affects the microbial activity during the process of biological leaching, which then affects the leaching of heavy metals from tailings. Experiments were carried out to examine the effect of temperature on heavy metal leaching in the temperature range of $7-42^{\circ} \mathrm{C}$, in which the growth rate of acidophilic bacteria varied with $\mathrm{pH}$, but the degree of change depended on the temperature [40]. Maintaining a constant temperature during large-scale operations is also a problem to be considered in the industrialization process of bioleaching of heavy metals from tailings.

2.2.3. Pulp Density. Previous studies on pulp density are scarce, but current studies show that pulp density mainly affects the leaching of heavy metals by affecting the $\mathrm{pH}$. The larger the pulp density, the greater the $\mathrm{pH}$ decline [9]. The effects of mineral pulp densities of 5,10 , and $30 \mathrm{~g} / \mathrm{L}$ on bacterial activity for different bacteria were investigated in a batch reactor. For A. thiooxidans, the higher the pulp density, the higher the $\mathrm{pH}$, while for $\mathrm{P}$. putida, the change in pulp density had no effect on the $\mathrm{pH}$ [41]. Because a high pulp density significantly inhibits microbial activity, when the pulp density was greater than $15 \%$, it had a great influence on the leaching rate of copper and zinc $[35,42]$.

2.2.4. Oxygen and Carbon Dioxide. A continuous oxygen supply is required during biological leaching. The oxygen and carbon dioxide contents are closely related to the activity of the microorganisms and affect the progress of the redox reaction. The monitoring of dissolved oxygen showed that the demand for oxygen increases with an increase in pulp density [43]. An empirical model of dimensionless parameters showed that biological leaching of manganese minerals by heterotrophic microorganisms occurred only under oxygen-limiting conditions [44]. The use of a higher dissolved oxygen concentration (above $4.1 \mathrm{mg} / \mathrm{L}$ ) inhibits the oxidation rate of ferrous ions. The optimal carbon dioxide concentration of ferrous oxidation ranges between 7 and $17 \%(\mathrm{~V} / \mathrm{V})$, and the oxidation rate of iron is severely limited when the carbon dioxide concentration is lower than 7\% [45].

2.2.5. Other Factors. In addition to the above common factors, there are the following new findings. For example, the leaching rate of heavy metals from tailings decreases with an increase in the solid concentration [46]. Furthermore, the activity of acidophilic bacteria in a stirred tank reactor under high pressure was studied for the first time, and the bacteria were found to remain active at a low oxygen partial pressure of +40 bar [47]. In a different study, ore particles of similar particle size fractions but different amounts of microcracks were prepared to investigate the influence of microcracks on bacterial activity, and the results showed that a larger number of microcracks were beneficial to bacterial growth and increased the bioleaching efficiency of copper by about $12.2 \%$ [48]. The effect of salinity was also investigated, and it was shown that low levels of salinity $(\leq 5 \mathrm{~g} / \mathrm{L}$ sodium chloride) have a positive effect on the bioleaching efficiency [49]. These new influencing factors are also important limiting conditions for the industrial production of heavy metals from biological leaching of mine tailings. Continuous research should be carried out to determine the optimal conditions for each factor to obtain the best metal leaching rate.

2.3. Research Hotspots of Biological Leaching Technologies. CiteSpace (5.7.R2) provides data visualization and network analysis capabilities [50]. Based on co-authors, cowords, and cluster analysis functions, CiteSpace can point out new trends and hot topics in a research area [51]. CiteSpace (5.7.R2) was used to analyze the research hotspots of bioleaching technologies with high objectivity of the results in this study. The core collection database of Web of Science was selected for basic retrieval. The retrieval topics were bioleaching and tailings, and a total of 157 records were retrieved. All data were exported, and CiteSpace was used for the visual analysis of keyword co-occurrence (Figure 3). Nodes in the graph shown in Figure 3 represent keywords, 


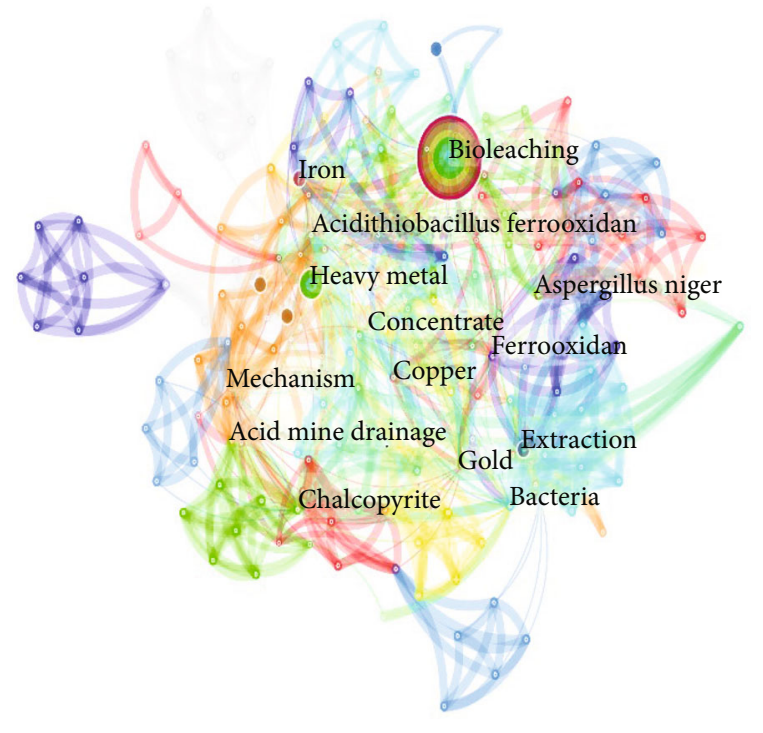

Figure 3: Research hotspots of bioleach technology (keywords cooccurrence).

edges represent the relationship between keywords, and circles represent the frequency of keywords. The main keywords shown are bioleaching, iron, heavy metals, Acidithiobacillus ferrooxidans, bacteria, extraction, and copper and are thus the current research hotspots. Table 3 shows the count, centrality, and earliest occurrence year of the keywords (arranged by frequency size).

Subsequently, a cluster analysis was conducted by selecting the label clusters with the indexing term function (Figure 4). On the resulting scale from 0 to 5 , the smaller the number, the more keywords are included in the cluster. The results showed that biocyanidation is the keyword with the largest storage capacity, and thus related research on this hot spot will be discussed below.

\subsection{Overview of Biological Leaching of Tailings}

2.4.1. Biological Leaching of Copper, Zinc, and Nickel Tailings. Copper was one of the first metals used by humans. Today, it is the most commonly used material for cables, electronics, electrical components, and construction; therefore, the demand for copper will continue to grow. Primary resources have been overexploited, and for sustainable development of resources, the development and utilization of tailings have become urgent. A survey of the copper content in tailings of the Musina mine, an abandoned copper mine in the northern Limpopo Province, showed that the residual copper currently stands at 8,555 tons [52]. As ore grades continue to decline, the byproducts of foam flotation are expected to produce copper tailings that still contain large amounts of unrecovered copper [53]. The tailings of Serbian copper ore were biologically leached with thermophilic acidophilus bacteria at $40^{\circ} \mathrm{C}$, and the best copper leaching rate obtained was $84 \%$ [54]. Analysis of copper ore obtained from the new base of Qarashoshaq in northern Zhylandy (Kazakhstan) showed that the highest extraction rate of copper was $95 \%$ by biological leaching and $66.8 \%$ by chemical leaching, indicating that
TABLE 3: Count, centrality, and earliest occurrence year of keywords.

\begin{tabular}{lccc}
\hline Count & Centrality & Year & Keywords \\
\hline 26 & 0.10 & 2009 & Bioleaching \\
10 & 0.15 & 2009 & Iron \\
10 & 0.05 & 2010 & Heavy metal \\
10 & 0.31 & 2009 & Acidithiobacillus ferrooxidan \\
8 & 0.20 & 2011 & Bacteria \\
7 & 0.10 & 2012 & Extraction \\
7 & 0.12 & 2009 & Copper \\
\hline
\end{tabular}

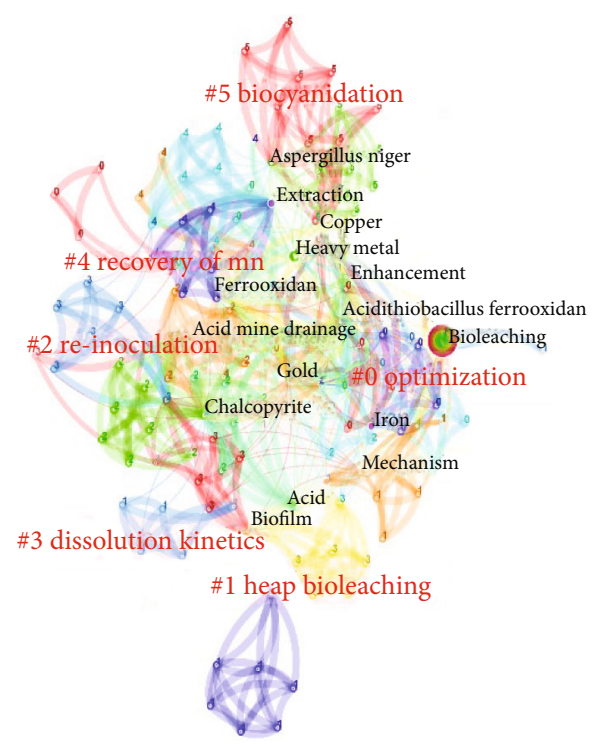

Figure 4: Analysis of label clusters with indexing terms.

the leaching rate of copper was higher for biological leaching [55]. At present, the biological leaching of oxide ores has not been thoroughly studied; however, Pseudomonas aeruginosa, a heterotrophic bacterium, has been used for biological leaching of copper oxide ores and zinc oxide ores, and $47 \%$ and $41 \%$ of copper and zinc were extracted, respectively [56]. Although the mechanism of combined leaching needs to be studied further, the recovery rate of copper under alkaline conditions was significantly improved when ammonia solution, and new alkaline bacteria were used [57]. In a study on the effect of magnetic induction intensity on the leaching rate of heavy metals, it was shown that the leaching rate of copper and arsenic increased with the increase of magnetic induction intensity, and when the magnetic induction intensity was $11 \mathrm{~m} \mathrm{~T}$, the metal leaching rate reached the best [58].

Metallic zinc is not only an irreplaceable material for batteries but also an essential trace element for the human body. Zinc resources mainly exist in the form of lead-zinc ore; thus, it is necessary to recover zinc from secondary resources. The potentially high mobilization and dispersion of zinc found in mine tailings in central Mexico can potentially harm the surrounding ecosystem [59]. Therefore, using bioleaching to recover zinc from tailings would solve two problems with one action. The zinc leaching rate was found to increase with an increase in temperature, reaching $96.96 \%$ at a temperature 
of $39.85^{\circ} \mathrm{C}$; based on Arrhenius's law of thermodynamics, the activation energy of the zinc bioleaching reaction was $39.557 \mathrm{~kJ} / \mathrm{mol}$ [60]. Moreover, the leaching rate of zinc was found to vary depending on the bacterial species and bacterial diversity. Analysis on an ore sample from a gold mine in northeastern Thailand showed a leaching rate of zinc that was six times higher with acidic thiobacillus ferric oxide as the microorganism than without the microorganism [61]. The tailings dam of the Kooshk lead-zinc mine was found to contain approximately $3.64 \%$ zinc, and more than $90 \%$ of sphalerite was leached within 14 days using mixed bacteria, but only $44 \%$ of zinc was extracted without bacteria [62]. In a study on the extraction of zinc from low-grade zinc concentrate by biological leaching, the results showed that the leaching rate of zinc was increased by $36 \%$ by thermophilic bacteria [63]. Yet, another study showed that the addition of starch and shredded newspaper increased the zinc bioleaching rate. In the presence of shredded newspaper and starch, the zinc leaching rates were $88 \%$ and $95 \%$, respectively, and the bioleaching time was reduced from 18 days to 10 days and 13 days, respectively [64].

Nickel was used as an excellent iron material in the early days. To control nickel tailing pollution, legume trees were planted on nickel tailings in the tropical area of Zimbabwe. After 20 and 40 years of restoration, different degrees of fertility islands were formed under the canopy of the legume plants [65]. A study of the bioleaching of tailings from the Tram Heap leaching plant in Finland found that some of the nickel dissolved in the primary heap reprecipitated and was retained in secondary ore, indicating that the nickel release was very rapid compared with abiotic experiments [66]. Biological leaching experiments were also carried out on ore samples of Brazilian nickel iron ore using a Bacillus subtilis strain. After 7 days, approximately $8.1 \% \mathrm{Ni}(0.7 \mathrm{mg}$ $\mathrm{Ni} / \mathrm{g}$ ore) was extracted. Meanwhile, pretreatment with microwave heating increased the biological extraction rate of nickel from $8 \%$ to $26 \%$ (2.3 mg Ni/g ore) [67]. A study analyzing pyrite and bentonite showed that, based on mineralogical characteristics, $\mathrm{Ni}$ is locked in pyrite and bentonite, and nickel leaching is thus related to the solubility of pyrite and bentonite; comparison of the leaching rate of nickel under aerobic and anoxic conditions at a $\mathrm{pH}$ of 1.5 showed that the optimal nickel leaching rate was obtained under aerobic conditions [68]. The bioleaching recovery of nickel from low-grade nickel-copper sulphide tailings was found to be as high as $91.5 \%$; furthermore, the nickel in the leaching mixture obtained by precipitation of sodium ettringite was enriched in the form of sulphide precipitation with a metal content of $8 \%$ [69]. However, the industrial application of bioleaching sulphide ores has made little progress. A new study showed that aerobic reductive dissolution (AeRD) using an A. thiooxidans and A. ferrooxidans consortium was able to extract $53-57 \%$ of nickel in just 7 days; this method not only uses less acid, thus reducing processing costs, but also includes a process of aerobic acid regeneration [70].

2.4.2. Biological Leaching of Rare and Precious Metals. The contents of rare earth elements in minerals are not as high as those of copper, zinc, iron, and other metals, but the unique optic, catalytic, electronic, and magnetic properties of rare earth elements make them invaluable in a number of advanced technological fields, especially their thermal stability, good electrical conductivity, and corrosion resistance [71]. With the rapid industrialization and modernization, technologies that rely heavily on rare earth elements, such as autocatalysts, rare earth magnets, rechargeable batteries, screens, hybrid cars, and low-energy lighting, are also developing rapidly, and the resources of rare earth elements have become insufficient [72]. While the development of secondary resources is a concern, so are the limitations of recycling technologies. Currently, many recycling technologies are based on biological leaching, continuous improvement, and innovation.

China has the world's largest rare earth element reserves by the mining value. In terms of global production, China (85\%) dominates, followed by Australia (10\%), Russia (2\%), India (1\%), Brazil (1\%), Malaysia, and Vietnam [73]. Rare earth elements play important roles in industry, medicine, military, and agriculture, and the consumption of rare earth element resources is very large worldwide; so, they have a certain economic value. According to the European Union and the US Department of Energy, a shortage of rare earth elements would have serious adverse economic effects [74]. The current rare earth element recovery research mostly focuses on electronic waste; however, some rare earth elements coexist with other minerals, and thus tailings will also become an important source of rare earth elements. Rare earth elements are commonly found in tungsten carbide, monazite, xenon ore, and recently adsorbed ion clays; therefore, acidic or alkaline recovery routes are required $[75,76]$. Both autotrophic and heterotrophic microorganisms can be used to leach rare earth elements $[77,78]$. In particular, Pseudomonas, Enterobacter, Serratia, and Bacillus have remarkable rare earth element recovery abilities in monazite ores $[79,80]$. In one study, different strain types and growth media were used to extract rare earth elements from rare earth element ore in China, and the results showed that the leaching efficiency of Streptomyces sp. FXJ1.172 was the highest, and the bioleaching efficiency of rare earth elements was improved by maximizing the carrier and acidity of real iron [81]. In addition to the selection of microorganisms, changes in the leaching conditions can also result in different leaching rates. Various rare earth elements can also be recovered effectively by using a high $\mathrm{Eh}$ and low $\mathrm{pH}$ leaching solution [82]. Bauxite contains complex and diverse rare earth elements, and organic acid bioleaching, reductive bioleaching, and oxidizing bioleaching were used in one study to recover its rare earth element content; the final recovery rate for the rare earth elements from neodymium to gadolinium was the highest, and the leaching rate of single rare earth elements ranged between $26.2 \%$ and $62.8 \%$ [83]. Furthermore, rare earth elements are also present in coal combustion residual fly ash and in one study were extracted from fly ash by Candida bombicola, Phanerochaete Chrysosporium, and Cryptococcus curvatus [84].

Biological leaching of precious metals occurs mainly through complexation and decomposition mechanisms of cyanogenic bacteria [85]. A pulp density of $20 \%$ (W/V) can 
result in a gold leaching rate of approximately 95\%, and the recovery of gold after biological oxidation can be as high as 95.7\% [86]. Precious metals are often lost in tailings owing to encapsulation of the precious metal particles in the ores. To solve this problem, tailing samples are pretreated by biological leaching before cyanide leaching, which has increased the leaching rate of gold to $95 \%$ and the leaching rate of silver to over $98 \%$ [87]. However, cyanide is toxic and poses environmental risks. In order to mitigate these risks, leaching methods using thiosulfate or halogen compounds instead of cyanide have been developed, and dump or heap bioleaching technologies also have a certain commercialization prospect [88]. Using an initial bacterial oxidation process, one study improved the leaching rate of gold from flotation tailings through biochemical leaching; $72 \%$ gold was extracted, $7 \%$ more than through the expensive sodium peroxide method, and $10 \%$ more than through the traditional cyanidation method [89]. Based on the latest literature, the recovery of gold from minerals is no longer achieved through the use of bioleaching technologies only, but through a combination with oxidation of microorganisms or the addition of new leaching agents in the bioleaching technologies, which greatly increases the recovery rate of gold. Further research will lead to the formation of a combined leaching method that is environmentally friendly and has a high leaching rate.

Similar to gold, silver has very little associated content, and biological leaching alone does not yield good leaching results. The silver tailings in Coahuila, Mexico, contain a large amount of silver mining waste, and the leaching efficiency of silver was found to be $40-67 \%$ using indigenous microbial leaching [90]. Lead and zinc tailings contain small amounts of valuable metals. To make full use of this secondary resource, high-temperature roasting combined with biological leaching was used to recover silver. At $900^{\circ} \mathrm{C}$, the leaching rate of silver reached $84.39 \%$, and the recovery amount of the leaching solution was $9.98 \mathrm{mg} / \mathrm{L}$ [91]. In a recent study, a pyrite-enhanced chlorination roasting technology achieved optimal gold and silver recoveries of $98.56 \%$ and $87.92 \%$, respectively, and reduced the emission of harmful gases compared with other additives [92]. The latest research results show that the recovery of silver has improved through the application of innovative technologies such as high-temperature roasting and chlorinated roasting of pyrite.

Uranium is radioactive, has a very long half-life, and is mainly used as nuclear fuel. Uranium resources are mainly distributed in the United States, Canada, and South Africa. Although large amounts of uranium exist in the Earth's crust, it is difficult to exploit these reserves due to technical limitations. However, uranium metal is an important raw material in nuclear physics, and primary uranium mineral resources have been overexploited. Thus, future exploration will be focused on the secondary recovery of waste resources such as tailings. The recovery of uranium from ores and tailings using bioleaching technologies would exceed the economic value of underground mining [93]. The current maximum leaching rate $(69 \%)$ was achieved within 60 days in a large column bioleaching experiment of $100 \mathrm{~kg}$ and $2 \mathrm{t}$ from an Indian uranium mine [94]. A summary of recent studies indicates that uranium ore is mainly treated by stacking, heap leaching, stope, and in situ biological leaching. Because uranium deposits contain rare earth elements, future bioleaching applications are likely to focus increasingly on these deposits, allowing for the full exploitation of metallic resources $[93,95]$.

2.4.3. Biological Leaching of Lead, Chromium, and Arsenic. Lead, chromium, and arsenic are toxic heavy metal pollutants. In the past, due to a lack of regulation and environmental protection consciousness, tailings piled up at random and caused widespread pollution of these metals, triggered a wide range of endemic diseases, thus posing a serious threat to human health. Today, pollution control of tailings is therefore mainly focused on these three metals.

In a study of lead concentrations in a 300-year-old abandoned mine tailings dam in Zacatecas, Mexico, the average level of lead was found to be $2,621 \pm 53 \mathrm{mg} / \mathrm{kg}$, significantly above international standards, with a risk of contamination mobility and possible inclusion in the food chain [96]. Lead can be recovered effectively from tailings using improved bioleaching technologies. Increasing the salt concentration and temperature can promote the recovery of lead; therefore, biological leaching combined with brine leaching can remove lead from lead and zinc tailings. Using only biological leaching under the best conditions to recover lead yielded $4.12 \%$ lead, while the addition of sodium chloride at a concentration of $150 \mathrm{~g} / \mathrm{L}$ to the biological leaching residues at $25^{\circ} \mathrm{C}$ recovered $94.70 \%$ of lead and at $50^{\circ} \mathrm{C}$ as much as $99.46 \%$ [97].

Treatments of chromium have mainly been developed to reduce hexavalent chromium to trivalent chromium, or to prevent the oxidation of trivalent chromium. Oxides of hexavalent chromium do not degrade by themselves and will accumulate in organisms for a long time. The industrial wastewater standard defines hexavalent chromium as a first-class pollutant, and many countries even prohibit products of hexavalent chromium electroplating from entering the market. The treatment of chromium pollution in tailings using bioleaching technologies is constantly being updated. Chromium-containing tailings are abundant in the Sukinda Valley, India. In a study on bioleaching of chromium, during the bioleaching process, the total chromium was initially extracted in the form of hexavalent chromium due to phosphate in the medium and was subsequently reduced due to hexavalent chromium adsorption and reduction to trivalent chromium [41].

An investigation of the metal content in agricultural soil near abandoned metal mines revealed that arsenic has a more profound impact on agricultural soil than the migration behavior of cadmium, lead, and zinc; therefore, the recovery of arsenic from tailings is crucial [98]. Experiments using the GEOCOAT $^{\mathrm{TM}}$ technology to remove arsenic from arsenicrich tailings showed a column bioleaching rate of more than 95\% and no effect of temperature on the arsenic leaching rate [99]. The biological leaching of arsenic from highconcentration arsenic tailings by A. ferrooxidans was found to be mainly affected by the pulp density and $\mathrm{pH}$. When the initial $\mathrm{pH}$ was changed from 2.0 to 2.2 , the leaching rate decreased by $45 \%$, and when the pulp density increased from 
$2.0 \%$ to $4.0 \%$, the leaching rate decreased by $55 \%$; thus, the $\mathrm{pH}$ range should be controlled, and the appropriate pulp density should be selected when leaching highconcentration arsenic tailings [100]. In another biological leaching study of arsenic from tailings with the high arsenic content (approximately 34,000 mg/kg), the leaching rate was mainly influenced by temperature and the solid concentration, with the leaching rate being the highest at $25^{\circ} \mathrm{C}$ and the lowest at $40^{\circ} \mathrm{C}$, and decreased with increasing solid concentration [101]. The differences in the factors affecting the bioleaching of arsenic in the two studies were due to the different leaching microorganisms used.

\section{Challenges and Opportunities for Bioleaching}

3.1. Challenges. In addition to laboratory-scale studies, treatment of tailings using bioleaching technologies has been performed at the industrial scale [102]. Industrial bioleaching processes are divided into irrigation-based principles (dump and heap bioleaching and in situ bioleaching) and vat- and stirred-tank bioleaching [93]. However, some factors limit industrialization.

Whether or not there is biomining or biofouling, the leaching mechanism between microorganisms and minerals is still complex [103]. The training period of microbes at the laboratory scale is long, and it is greatly influenced by other experimental conditions. Therefore, the key to improving the ease of operation of bioleaching technologies in largescale industrial production is to improve existing bioleaching microorganisms so that they can remain highly active under more complex reaction conditions. In addition, regarding the microbial challenge [104], biological leaching heaps of only a handful of genes in the derivative of acidophilic microorganisms have been published. Although some bacterial genomes from acid mine drainage (AMD) and acidic environments have been used to build replacements, these models cannot fully show the leaching potential; at the same time, it is difficult for researchers to obtain samples of microbes from actual production, making further research difficult.

Cadmium in tailing soil is mainly bound to organic matter and appears in different mineral phases. The bioavailability sequence of lead and cadmium in soil is cadmium $>$ lead $>$ zinc, with the highest content of cadmium in the soil at around 200-400 $\mathrm{m}$ of tailings [105]. Cadmium inhibits the decomposition of leaf litter by affecting the activity of earthworms and leads to the degradation of soil fertility [106]. Therefore, the treatment of cadmium-containing tailings is very important. A literature review revealed that due to the low efficiency of cadmium bioleaching, there are currently few studies on bioleaching of cadmium pollution in tailings, but those carried out mainly used acid washing, phytoremediation, and other technologies [107, 108]. In the future, it will be necessary to further improve cadmium bioleaching technologies to obtain a higher leaching rate according to the characteristics of cadmium.

Increasing the size of instruments is also a challenge. The small reaction equipment in laboratories enables reactions to be carried out fully, but in large-scale industrial production, the reaction containers are large, and the $\mathrm{pH}$, oxygen concen- tration, and microbial distribution of the solution cannot be maintained, which leads to a decrease in bioleaching rates.

Following biological leaching, the filter residue may still contain unleachable heavy metals; therefore, follow-up treatment of the filter residue is also a challenge.

3.2. Opportunities. Compared with traditional physical and chemical techniques, biotechnology is characterized by more creative options for metal extraction and processing [109]. In tailings treatment, the emergence of biological leaching technologies has made up for the shortcomings of physicochemical remediation technologies. However, these technologies still have a high potential for growth.

At present, the indigenous microorganisms used in biological leaching experiments provide excellent genetic data. These data can be used to synthesize microorganisms that meet the requirements of industrial-scale biological leaching of heavy metal tailings through gene recombination to improve the leaching efficiency, reduce industrial costs, and make full use of tailing resources [110]. Future advances in biogenomics will overcome microbial constraints. It will also greatly promote the development of microbial leaching and chlorine-resistant organisms in alkaline environments.

Additional factors influencing biological leaching of heavy metals from tailings have been found recently, which creates new opportunities to improve metal leaching rates. Most of the factors affect the leaching rate by affecting microbial activity. Therefore, future research can build on this breakthrough to enable microorganisms to have genes such as resistance to high pressure and salinity to obtain a greater leaching rate of heavy metals.

Leaching technologies for rare earth elements have also been developed. Owing to the low content of rare earth elements in tailings, biological leaching alone cannot maximize the exploitation of such secondary resources. Innovative technologies such as high-temperature roasting combined with biological leaching, cyanide leaching combined with biological leaching, and bacterial oxidation combined with biological leaching have thus been developed. In addition, through the development of enzymes for biological leaching reactions, heavy metals can be selectively leached from tailings, which can not only improve the metal leaching rate and economic value but also carry out effective treatment for metal pollution [111].

The residue from biological leaching of tailings has also been studied further. One study reported that following recovery treatment of an arsenic/nickel/cobalt leaching residue, the leaching rates of copper, cobalt, nickel, zinc, and arsenic reached 96.31\%, 97.23\%, 98.56\%, 98.46\%, and $93.84 \%$, respectively, which is conducive to the effective utilization of resources and reduces the waste of mineral resources [112].

\section{Conclusion}

Bioleaching is a sustainable method for metal recovery from tailings and controlling their pollution, which can help save nonrenewable energy consumed in the mining industry and make full use of this secondary resource. In this review, 
previously published results obtained in the field of bioleaching of tailings were reviewed and presented, including the bioleaching mechanism, the type of influencing factors, and the type of tailings. This review shows that the technologies used for the bioleaching of tailings are mature. In addition to the conventional influencing factors, research on factors such as pressure, microcracks, and salinity has provided new paths for improving the rates of metal leaching. The application of CiteSpace (5.7R2) intuitively visualized that the research hotspots of bioleaching of tailings mainly include biocyanidation, the recovery of manganese, and dissolution kinetics. The discovery of new leaching microorganisms, development of biogenomics, and combination of biocyanidation are new opportunities for the industrial production of heavy metals from bioleaching tailings. The main future development directions identified in this review are the development of the industrial production of heavy metal recovery through biological leaching of mine tailings, while constantly optimizing the process, and to create higher economic and ecological benefits.

\section{Data Availability}

The data used to support the findings of this study are available from the corresponding author upon request.

\section{Conflicts of Interest}

The authors declare that they have no conflicts of interest.

\section{References}

[1] M. N. Uugwanga and N. A. Kgabi, “Assessment of metals pollution in sediments and tailings of Klein Aub and Oamites mine sites, Namibia," Environmental Advances, vol. 2, article 100006, 2020.

[2] B. L. Larner, A. J. Seen, and A. T. Townsend, "Comparative study of optimised BCR sequential extraction scheme and acid leaching of elements in the certified reference material NIST 2711," Analytica Chimica Acta, vol. 556, no. 2, pp. 444-449, 2006.

[3] Z. Song, G. Song, W. Tang et al., "Molybdenum contamination dispersion from mining site to a reservoir," Ecotoxicology and Environmental Safety, vol. 208, article 111631, 2021.

[4] G. Belle, A. Fossey, L. Esterhuizen, and R. Moodley, "Contamination of groundwater by potential harmful elements from gold mine tailings and the implications to human health: a case study in Welkom and Virginia, Free State Province, South Africa," Groundwater for Sustainable Development, vol. 12, article 100507, 2021.

[5] F. Perlatti, E. P. Martins, D. P. de Oliveira et al., "Copper release from waste rocks in an abandoned mine (NE, Brazil) and its impacts on ecosystem environmental quality," Chemosphere, vol. 262, article 127843, 2021.

[6] A. Kicińska and J. Wikar, "Ecological risk associated with agricultural production in soils contaminated by the activities of the metal ore mining and processing industry - example from southern Poland," Soil and Tillage Research, vol. 205, article 104817, 2021.

[7] Q. Yin, "Trend of development of large-scale copper mines," Nonferrous Metals, no. 6, 2007.
[8] R. K. Jyothi, T. Thenepalli, J. W. Ahn, P. K. Parhi, K. W. Chung, and J.-Y. Lee, "Review of rare earth elements recovery from secondary resources for clean energy technologies: grand opportunities to create wealth from waste," Journal of Cleaner Production, vol. 267, article 122048, 2020.

[9] M. Ye, G. Li, P. Yan et al., "Removal of metals from lead-zinc mine tailings using bioleaching and followed by sulfide precipitation," Chemosphere, vol. 185, pp. 1189-1196, 2017.

[10] J. Zeng, M. Gou, Y.-Q. Tang, G.-Y. Li, Z.-Y. Sun, and K. Kida, "Effective bioleaching of chromium in tannery sludge with an enriched sulfur- oxidizing bacterial community," Bioresource Technology, vol. 218, pp. 859-866, 2016.

[11] S. R. Zimmerley, D. G. Wilson, and J. D. Prater, Cyclic leaching process employing iron oxidizing bacteria, KENNECOTT COPPER CORP, United States, 1958.

[12] H. Watling, "Review of biohydrometallurgical metals extraction from polymetallic mineral resources," Minerals, vol. 5, no. 1, pp. 1-60, 2014.

[13] C. L. Brierley, "How will biomining be applied in future?" Transactions of Nonferrous Metals Society of China, vol. 18, no. 6, pp. 1302-1310, 2008.

[14] V. Gopikrishnan, A. Vignesh, M. Radhakrishnan et al., "Microbial leaching of heavy metals from e-waste," in Biovalorisation of Wastes to Renewable Chemicals and Biofuels, N. K. Rathinam and R. K. Sani, Eds., pp. 189-216, Elsevier, 2020.

[15] K. A. Natarajan, "Bioleaching Mechanisms," in Biotechnology of Metals, K. A. Natarajan, Ed., pp. 49-80, Elsevier, Amsterdam, 2018.

[16] V. Fonti, A. Dell'Anno, and F. Beolchini, "Does bioleaching represent a biotechnological strategy for remediation of contaminated sediments?," Science of The Total Environment, vol. 563-564, pp. 302-319, 2016.

[17] K. Bosecker, "Bioleaching: metal solubilization by microorganisms," FEMS Microbiology Reviews, vol. 20, no. 3-4, pp. 591-604, 1997.

[18] H. Tributsch, "Direct versus indirect bioleaching," Hydrometallurgy, vol. 59, no. 2-3, pp. 177-185, 2001.

[19] R. D. Tyagi, J. F. Blais, and J. C. Auclair, "Bacterial leaching of metals from sewage sludge by indigenous iron-oxidizing bacteria," Environmental Pollution, vol. 82, no. 1, pp. 9-12, 1993.

[20] M. P. Silverman, "Mechanism of bacterial pyrite oxidation," Journal of Bacteriology, vol. 94, no. 4, pp. 1046-1051, 1967.

[21] Y.-G. Liu, M. Zhou, G.-M. Zeng et al., "Bioleaching of heavy metals from mine tailings by indigenous sulfur-oxidizing bacteria: effects of substrate concentration," Bioresource Technology, vol. 99, no. 10, pp. 4124-4129, 2008.

[22] A. Pathak, M. G. Dastidar, and T. R. Sreekrishnan, "Bioleaching of heavy metals from sewage sludge by indigenous ironoxidizing microorganisms using ammonium ferrous sulfate and ferrous sulfate as energy sources: a comparative study," Journal of Hazardous Materials, vol. 171, no. 1-3, pp. 273278, 2009.

[23] J.-U. Lee, S.-W. Lee, H.-T. Chon, K.-W. Kim, and J.-S. Lee, "Enhancement of arsenic mobility by indigenous bacteria from mine tailings as response to organic supply," Environment International, vol. 35, no. 3, pp. 496-501, 2009.

[24] X.-d. Hao, X.-d. Liu, Q. Yang et al., "Comparative study on bioleaching of two different types of low-grade copper tailings by mixed moderate thermophiles," Transactions of Nonferrous Metals Society of China, vol. 28, no. 9, pp. 1847-1853, 2018. 
[25] B. M. Goebel and E. Stackebrandt, "Cultural and phylogenetic analysis of mixed microbial populations found in natural and commercial bioleaching environments," Applied and environmental microbiology, vol. 60, no. 5, pp. 1614-1621, 1994.

[26] V. K. Nguyen, M. H. Lee, H. J. Park, and J.-U. Lee, "Bioleaching of arsenic and heavy metals from mine tailings by pure and mixed cultures of Acidithiobacillus spp.," Journal of Industrial and Engineering Chemistry, vol. 21, pp. 451-458, 2015.

[27] L. Wang, S. Yin, A. Wu, and W. Chen, "Synergetic bioleaching of copper sulfides using mixed microorganisms and its community structure succession," Journal of Cleaner Production, vol. 245, article 118689, 2020.

[28] N. Vardanyan, G. Sevoyan, T. Navasardyan, and A. Vardanyan, "Recovery of valuable metals from polymetallic mine tailings by natural microbial consortium," Environmental Technology, vol. 40, no. 26, pp. 3467-3472, 2019.

[29] D. E. Rawlings, "Characteristics and adaptability of iron- and sulfur-oxidizing microorganisms used for the recovery of metals from minerals and their concentrates," Microbial Cell Factories, vol. 4, no. 1, p. 13, 2005.

[30] H. Brandl, "Microbial leaching of metals," Biotechnology, vol. 10, pp. 191-224, 2001.

[31] D. E. Rawlings and D. B. Johnson, "The microbiology of biomining: development and optimization of mineral-oxidizing microbial consortia," Microbiology (Reading, England), vol. 153, no. 2, pp. 315-324, 2007.

[32] C. L. Brierley, "Bacterial succession in bioheap leaching," Hydrometallurgy, vol. 59, no. 2-3, pp. 249-255, 2001.

[33] C. Johansson, V. Shrader, J. Suissa, K. Adutwum, and W. Kohr, "Use of the GEOCOAT ${ }^{\mathrm{TM}}$ process for the recovery of copper from chalcopyrite," in Process Metallurgy, R. Amils and A. Ballester, Eds., pp. 569-576, Elsevier, 1999.

[34] M. Baniasadi, F. Vakilchap, N. Bahaloo-Horeh, S. M. Mousavi, and S. Farnaud, "Advances in bioleaching as a sustainable method for metal recovery from e-waste: a review," Journal of Industrial and Engineering Chemistry, vol. 76, pp. 75-90, 2019.

[35] Z. Guo, L. Zhang, Y. Cheng, X. Xiao, F. Pan, and K. Jiang, "Effects of $\mathrm{pH}$, pulp density and particle size on solubilization of metals from a $\mathrm{Pb} / \mathrm{Zn}$ smelting slag using indigenous moderate thermophilic bacteria," Hydrometallurgy, vol. 104, no. 1, pp. 25-31, 2010.

[36] J. W. C. Wong, L. Xiang, and L. C. Chan, "pH requirement for the bioleaching of heavy metals from anaerobically digested wastewater sludge," Water, Air, and Soil Pollution, vol. 138, no. 1/4, pp. 25-35, 2002.

[37] T. R. Sreekrishnan, R. D. Tyagi, J. F. Blais, and P. G. C. Campbell, "Kinetics of heavy metal bioleaching from sewage sludge-I. Effects of process parameters," Water Research, vol. 27, no. 11, pp. 1641-1651, 1993.

[38] K. A. Third, R. Cord-Ruwisch, and H. R. Watling, "The role of iron-oxidizing bacteria in stimulation or inhibition of chalcopyrite bioleaching," Hydrometallurgy, vol. 57, no. 3, pp. 225-233, 2000.

[39] J. Vilcáez, K. Suto, and C. Inoue, "Bioleaching of chalcopyrite with thermophiles: Temperature-pH-ORP dependence," International Journal of Mineral Processing, vol. 88, no. 1-2, pp. 37-44, 2008.

[40] R. D. Tyagi, T. R. Sreekrishnan, J. F. Blais, and P. G. C. Campbell, "Kinetics of heavy metal bioleaching from sewage
sludge-III. Temperature effects," Water Research, vol. 28, no. 11 , pp. $2367-2375,1994$.

[41] V. Bolaños-Benítez, E. D. van Hullebusch, P. N. L. Lens et al., "(Bio)leaching behavior of chromite tailings," Minerals, vol. 8, no. 6, p. 261, 2018.

[42] S. M. Mousavi, S. Yaghmaei, M. Vossoughi, A. Jafari, and S. A. Hoseini, "Comparison of bioleaching ability of two native mesophilic and thermophilic bacteria on copper recovery from chalcopyrite concentrate in an airlift bioreactor," Hydrometallurgy, vol. 80, no. 1-2, pp. 139-144, 2005.

[43] J. Y. Witne and C. V. Phillips, "Bioleaching of Ok Tedi copper concentrate in oxygen- and carbon dioxide- enriched air," Minerals Engineering, vol. 14, no. 1, pp. 25-48, 2001.

[44] F. Veglio, F. Beolchini, and S. Ubaldini, "Empirical models for oxygen mass transfer: a comparison between shake flask and lab-scale fermentor and application to manganiferous ore bioleaching," Process Biochemistry, vol. 33, no. 4, pp. 367-376, 1998.

[45] S. H. de Kock, P. Barnard, and C. A. du Plessis, "Oxygen and carbon dioxide kinetic challenges for thermophilic mineral bioleaching processes," Biochemical Society transactions, vol. 32, no. 2, pp. 273-275, 2004.

[46] Y.-G. Liu, M. Zhou, G.-M. Zeng, X. Li, W.-H. Xu, and T. Fan, "Effect of solids concentration on removal of heavy metals from mine tailings via bioleaching," Journal of Hazardous Materials, vol. 141, no. 1, pp. 202-208, 2007.

[47] R. Hajdu-Rahkama, S. Ahoranta, A.-M. Lakaniemi, and J. A. Puhakka, "Effects of elevated pressures on the activity of acidophilic bioleaching microorganisms," Biochemical Engineering Journal, vol. 150, article 107286, 2019.

[48] J. Chen, D. Tang, S. Zhong, W. Zhong, and B. Li, "The influence of micro-cracks on copper extraction by bioleaching," Hydrometallurgy, vol. 191, article 105243, 2020.

[49] S. M. Sadeghieh, A. Ahmadi, and M. R. Hosseini, "Effect of water salinity on the bioleaching of copper, nickel and cobalt from the sulphidic tailing of Golgohar Iron Mine, Iran," Hydrometallurgy, vol. 198, article 105503, 2020.

[50] C. Chen, "CiteSpace: A Practical Guide for Mapping Scientific Literature," 2016.

[51] P. Wu, Z. Wang, H. Wang, N. S. Bolan, Y. Wang, and W. Chen, "Visualizing the emerging trends of biochar research and applications in 2019: a scientometric analysis and review," Biochar, vol. 2, no. 2, pp. 135-150, 2020.

[52] N. K. Singo and J. D. Kramers, "Retreatability analysis of the Musina copper mine tailings in South Africa: an exploratory study," SN Applied Sciences, vol. 2, no. 10, article 1707, 2020.

[53] X.-1. Zhang, J. Kou, C.-b. Sun, R.-y. Zhang, M. Su, and S.-f. Li, "Insights into mineralogical characteristics of typical copper sulfide tailings using automated mineral liberation analysis: a case study from the Chambishi Copper Mine," International Journal of Minerals, Metallurgy and Materials, vol. 27, 2020.

[54] V. Conić, S. Stanković, B. Marković, D. Božić, J. Stojanović, and M. Sokić, "Investigation of the optimal technology for copper leaching from old flotation tailings of the copper mine bor (Serbia)," Metallurgical and Materials Engineering, vol. 26, no. 2, pp. 209-222, 2020.

[55] N. K. Zhappar, V. M. Shaikhutdinov, Y. N. Kanafin et al., "Bacterial and chemical leaching of copper-containing ores with the possibility of subsequent recovery of trace silver," 
Chemical Papers, vol. 73, no. 6, article 688, pp. 1357-1367, 2019.

[56] M. A. Shabani, M. Irannajad, M. Meshkini, and A. R. Azadmehr, "Investigations on bioleaching of copper and zinc oxide ores," Transactions of the Indian Institute of Metals, vol. 72, no. 3, article 1509, pp. 609-611, 2019.

[57] S. Yin, L. Wang, A. Wu, E. Kabwe, X. Chen, and R. Yan, "Copper recycle from sulfide tailings using combined leaching of ammonia solution and alkaline bacteria," Journal of Cleaner Production, vol. 189, pp. 746-753, 2018.

[58] L. Lu, D. Li, and J. Jiang, "Strengthening of bioleaching of $\mathrm{Cu}$ and As by static magnetic field with Acidithiobacillus ferriooxidans in tailings," in 2016 5th International Conference on Advanced Materials and Computer Science (ICAMCS 2016), pp. 205-209, Atlantis Press, Qingdao, China, 2016.

[59] G. Cruz-Jiménez, R. Loredo-Portales, R. Del Rio-Salas et al., "Multi-synchrotron techniques to constrain mobility and speciation of $\mathrm{Zn}$ associated with historical mine tailings," Chemical Geology, vol. 558, article 119866, 2020.

[60] V. P. Sundramurthy, B. Rajoo, N. R. Srinivasan, and R. Kavitha, "Bioleaching of $\mathrm{Zn}$ from sphalerite using Leptospirillum ferriphilum isolate: effect of temperature and kinetic aspects," Applied Biological Chemistry, vol. 63, no. 1, p. 44, 2020.

[61] P. Kaewkannetra, F. J. Garcia-Garcia, and T. Y. Chiu, "Bioleaching of zinc from gold ores using Acidithiobacillus ferrooxidans," International Journal of Minerals, Metallurgy and Materials, vol. 16, no. 4, pp. 368-374, 2009.

[62] J. V. Mehrabani, S. Z. Shafaei, M. Noaparast, S. M. Mousavi, and M. M. Rajaei, "Bioleaching of sphalerite sample from Kooshk lead-zinc tailing dam," Transactions of Nonferrous Metals Society of China, vol. 23, no. 12, pp. 3763-3769, 2013.

[63] J. V. Mehrabani, S. Z. Shafaei, M. Noaparast, and M. Mousavi, "Bioleaching of a low grade sphalerite concentrate produced from flotation tailings," International Journal of Mining and Geo-Engineering, vol. 50, pp. 169-173, 2016.

[64] A. Foroutan, S. Bazpors Ghaziani, M. Abbas Zadeh Haji Abadi, S. Shirazian, and M. Ghadiri, "Intensification of zinc bioleaching from a zinc-iron bearing ore by condition optimization and adding catalysts," Transactions of the Indian Institute of Metals, vol. 74, no. 1, article 2117, pp. 1-8, 2021.

[65] T. Nyenda, W. Gwenzi, C. Gwata, and S. M. Jacobs, "Leguminous tree species create islands of fertility and influence the understory vegetation on nickel-mine tailings of different ages," Ecological Engineering, vol. 155, article 105902, 2020.

[66] A. Hubau, A.-G. Guezennec, C. Joulian, C. Falagán, D. Dew, and K. A. Hudson-Edwards, "Bioleaching to reprocess sulfidic polymetallic primary mining residues: determination of metal leaching mechanisms," Hydrometallurgy, vol. 197, article 105484, 2020.

[67] E. C. Giese, H. L. Carpen, L. C. Bertolino, and C. L. Schneider, "Characterization and bioleaching of nickel laterite ore using Bacillus subtilis strain," Biotechnology Progress, vol. 35, no. 6, article e2860, 2019.

[68] S. Garg, K. Judd, R. Mahadevan, E. Edwards, and V. G. Papangelakis, "Leaching characteristics of nickeliferous pyrrhotite tailings from the Sudbury, Ontario area," Canadian Metallurgical Quarterly, vol. 56, no. 4, pp. 372-381, 2017.

[69] Y. Xie, Y. Xu, L. Yan, and R. Yang, "Recovery of nickel, copper and cobalt from low-grade Ni-Cu sulfide tailings," Hydrometallurgy, vol. 80, no. 1-2, pp. 54-58, 2005.
[70] J. Marrero, O. Coto, S. Goldmann, T. Graupner, and A. Schippers, "Recovery of nickel and cobalt from laterite tailings by reductive dissolution under aerobic conditions using Acidithiobacillus species," Environmental Science \& Technology, vol. 49, no. 11, pp. 6674-6682, 2015.

[71] M. M. Wang, Q. Y. Tan, J. F. Chiang, and J. H. Li, "recovery of rare and precious metals from urban mines-a review," Frontiers of Environmental Science \& Engineering, vol. 11, no. 5, p. 17, 2017.

[72] A. M. Mowafy, "Biological leaching of rare earth elements," World Journal of Microbiology and Biotechnology, vol. 36, no. 4, p. 61, 2020.

[73] B. Zhou, Z. Li, and C. Chen, "Global potential of rare earth resources and rare earth demand from clean technologies," Minerals, vol. 7, no. 11, p. 203, 2017.

[74] K. Binnemans, P. T. Jones, B. Blanpain et al., "Recycling of rare earths: a critical review," Journal of Cleaner Production, vol. 51, pp. 1-22, 2013.

[75] S. Peelman, Z. H. I. Sun, J. Sietsma, and Y. Yang, "Chapter 21 - leaching of rare earth elements: review of past and present technologies," in Rare Earths Industry, I. Borges De Lima and W. Leal Filho, Eds., pp. 319-334, Elsevier, Boston, 2016.

[76] N. Haque, A. E. Hughes, K. Lim, and C. Vernon, "Rare earth elements: overview of mining, mineralogy, uses, sustainability and environmental impact," Resources, vol. 3, no. 4, pp. 614-635, 2014.

[77] Y. Qu and B. Lian, "Bioleaching of rare earth and radioactive elements from red mud using Penicillium tricolor RM-10," Bioresource Technology, vol. 136, pp. 16-23, 2013.

[78] J.-A. Kim, G. Dodbiba, Y. Tanimura et al., "Leaching of rareearth elements and their adsorption by using blue-green algae," MATERIALS TRANSACTIONS, vol. 52, no. 9, pp. 1799-1806, 2011.

[79] V. L. Brisson, W.-Q. Zhuang, and L. Alvarez-Cohen, "Bioleaching of rare earth elements from monazite sand," Biotechnology and Bioengineering, vol. 113, no. 2, pp. 339-348, 2016.

[80] D. Shin, J. Kim, B.-s. Kim, J. Jeong, and J.-c. Lee, "Use of phosphate solubilizing bacteria to leach rare earth elements from monazite-bearing ore," Minerals, vol. 5, no. 2, pp. 189-202, 2015.

[81] L. Zhang, H. Dong, Y. Liu et al., "Bioleaching of rare earth elements from bastnaesite-bearing rock by actinobacteria," Chemical Geology, vol. 483, pp. 544-557, 2018.

[82] P. K. Sarswat, M. Leake, L. Allen et al., "Efficient recovery of rare earth elements from coal based resources: a bioleaching approach," Materials Today Chemistry, vol. 16, article 100246, 2020.

[83] M. J. Barnett, B. Palumbo-Roe, E. A. Deady, and S. P. Gregory, "Comparison of three approaches for bioleaching of rare earth elements from bauxite," Minerals, vol. 10, no. 8, p. 649, 2020.

[84] S. Park and Y. Liang, "Bioleaching of trace elements and rare earth elements from coal fly ash," International Journal of Coal Science \& Technology, vol. 6, no. 1, article 238, pp. 7483, 2019.

[85] S. B. Tay, G. Natarajan, M. N. . A. Rahim et al., "Enhancing gold recovery from electronic waste via lixiviant metabolic engineering in Chromobacterium violaceum," Scientific Reports, vol. 3, no. 1, article 2236, 2013.

[86] M. L. M. Rodrigues, R. M. N. Giardini, I. J. U. V. Pereira, and V. A. Leão, "Recovering gold from mine tailings: a selection 
of reactors forbio-oxidationat high pulp densities," Journal of Chemical Technology \& Biotechnology, vol. 96, no. 1, pp. 217226, 2020.

[87] Y. A. Attia and M. El-Zeky, "Bioleaching of gold pyrite tailings with adapted bacteria," Hydrometallurgy, vol. 22, no. 3, pp. 291-300, 1989.

[88] S.-h. Lee, "Current status of gold leaching technologies from low grade ores or tailings," Journal of the Korean Institute of Resources Recycling, vol. 29, pp. 3-7, 2020.

[89] A. Koizhanova, B. Kenzhaliyev, D. Magomedov, E. Kamalov, M. Erdenova, and N. Abdyldaev, "A study of the biohydrometallurgical method for extracting gold from flotation tailings," Metalurgija, vol. 59, pp. 477-480, 2020.

[90] B. Huerta-Rosas, I. Cano-Rodríguez, Z. Gamiño-Arroyo et al., "Aerobic processes for bioleaching manganese and silver using microorganisms indigenous to mine tailings," World Journal of Microbiology and Biotechnology, vol. 36, no. 8, p. 124, 2020.

[91] C. Lei, B. Yan, T. Chen, X.-L. Wang, and X.-M. Xiao, "Silver leaching and recovery of valuable metals from magnetic tailings using chloride leaching," Journal of Cleaner Production, vol. 181, pp. 408-415, 2018.

[92] H. Qin, X. Guo, Q. Tian, and L. Zhang, "Pyrite enhanced chlorination roasting and its efficacy in gold and silver recovery from gold tailing," Separation and Purification Technology, vol. 250, article 117168, 2020.

[93] B. D. Abhilash and B. D. Pandey, "Microbially assisted leaching of uranium -a review," Mineral Processing and Extractive Metallurgy Review, vol. 34, no. 2, pp. 81-113, 2013.

[94] K. D. Abhilash, V. Mehta, B. D. Kumar, P. K. Pandey, and P. K. Tamrakar, "Bioleaching - an alternate uranium ore processing technology for India," Energy Procedia, vol. 7, pp. 158-162, 2011.

[95] A. H. Kaksonen, A.-M. Lakaniemi, and O. H. Tuovinen, "Acid and ferric sulfate bioleaching of uranium ores: A review," Journal of Cleaner Production, vol. 264, article 121586, 2020.

[96] J. A. Flores de la Torre, K. Mitchell, M. S. Ramos Gómez, A. L. Guerrero Barrera, L. Yamamoto Flores, and F. J. Avelar González, "Effect of plant growth on $\mathrm{Pb}$ and $\mathrm{Zn}$ geoaccumulation in 300-year-old mine tailings of Zacatecas, México," Environmental Earth Sciences, vol. 77, no. 10, p. 386, 2018.

[97] M. Ye, P. Yan, S. Sun et al., "Bioleaching combined brine leaching of heavy metals from lead-zinc mine tailings: Transformations during the leaching process," Chemosphere, vol. 168, pp. 1115-1125, 2017.

[98] S.-W. Yun, D.-H. Kang, W.-H. Ji, M.-H. Jung, and C. Yu, "distinct dispersion of as, $\mathrm{cd}, \mathrm{Pb}$, and $\mathrm{Zn}$ in farmland soils near abandoned mine tailings: field observation results in South Korea," Journal of Chemistry, vol. 2020, Article ID 9671871, 13 pages, 2020.

[99] E. Ngoma, D. Borja, M. Smart et al., "Bioleaching of arsenopyrite from Janggun mine tailings (South Korea) using an adapted mixed mesophilic culture," Hydrometallurgy, vol. 181, pp. 21-28, 2018.

[100] J. Park, Y. Han, E. Lee et al., "Bioleaching of highly concentrated arsenic mine tailings by Acidithiobacillus ferrooxidans," Separation and Purification Technology, vol. 133, pp. 291-296, 2014.

[101] E. Lee, Y. Han, J. Park et al., "Bioleaching of arsenic from highly contaminated mine tailings using Acidithiobacillus thiooxidans," Journal of Environmental Management, vol. 147, pp. 124-131, 2015.

[102] J. Mäkinen, M. Salo, M. Khoshkhoo, J.-E. Sundkvist, and P. Kinnunen, "Bioleaching of cobalt from sulfide mining tailings; a mini-pilot study," Hydrometallurgy, vol. 196, article 105418, 2020 .

[103] A. Thosar, P. Satpathy, T. Nathiya, and A. Rajan, "Biomining: a revolutionizing technology for a safer and greener environment," International Journal of Recent Scientific Research, vol. 5, pp. 1624-1632, 2014

[104] J. P. Cárdenas, R. Quatrini, and D. S. Holmes, "Genomic and metagenomic challenges and opportunities for bioleaching: a mini- review," Research in Microbiology, vol. 167, no. 7, pp. 529-538, 2016.

[105] I. Elmayel, J. M. Esbri, G. O. Efren et al., "Evolution of the speciation and mobility of $\mathrm{Pb}, \mathrm{Zn}$ and $\mathrm{Cd}$ in relation to transport processes in a mining environment," International journal of environmental research and public health, vol. 17, no. 14 , p. 4912, 2020.

[106] C. Liu, C. Duan, X. Meng et al., "Cadmium pollution alters earthworm activity and thus leaf-litter decomposition and soil properties," Environmental Pollution, vol. 267, article 115410, 2020.

[107] A. Rakshit, S. Pal, M. Parihar, and H. B. Singh, "Bioremediation of soils contaminated with $\mathrm{Ni}$ and Cd: an overview," in Adaptive Soil Management : From Theory to Practices, A. Rakshit, P. C. Abhilash, H. B. Singh, and S. Ghosh, Eds., pp. 339-357, Springer, Singapore, 2017.

[108] Y. Wu, J. Yang, J. Tang, P. Kerr, and P. K. Wong, "The remediation of extremely acidic and moderate $\mathrm{pH}$ soil leachates containing $\mathrm{Cu}$ (II) and Cd (II) by native periphytic biofilm," Journal of Cleaner Production, vol. 162, pp. 846-855, 2017.

[109] K. A. Natarajan, "Chapter 1 - introduction-status and scope of metals biotechnology," in Biotechnology of Metals, K. A. Natarajan, Ed., pp. 1-5, Elsevier, Amsterdam, 2018.

[110] P. S. Kumar and P. R. Yaashikaa, "Chapter 20 - Recent trends and challenges in bioleaching technologies," in Biovalorisation of Wastes to Renewable Chemicals and Biofuels, N. K. Rathinam and R. K. Sani, Eds., pp. 373-388, Elsevier, 2020.

[111] D. Borja, K. A. Nguyen, R. A. Silva et al., "Experiences and future challenges of bioleaching research in South Korea," Minerals, vol. 6, no. 4, p. 128, 2016.

[112] J. Qiao, A. Chen, X. Sun et al., "Recovery of valuable metals from the leaching tailings from the arsenic/nickel/cobalt residue," in Characterization of Minerals, Metals, and Materials 2020, J. Li, M. Zhang, B. Li, S. N. Monteiro, S. Ikhmayies, Y. E. Kalay, J.-Y. Hwang, J. P. Escobedo-Diaz, J. S. Carpenter, and A. D. Brown, Eds., pp. 141-152, Springer International Publishing, Cham, 2020. 